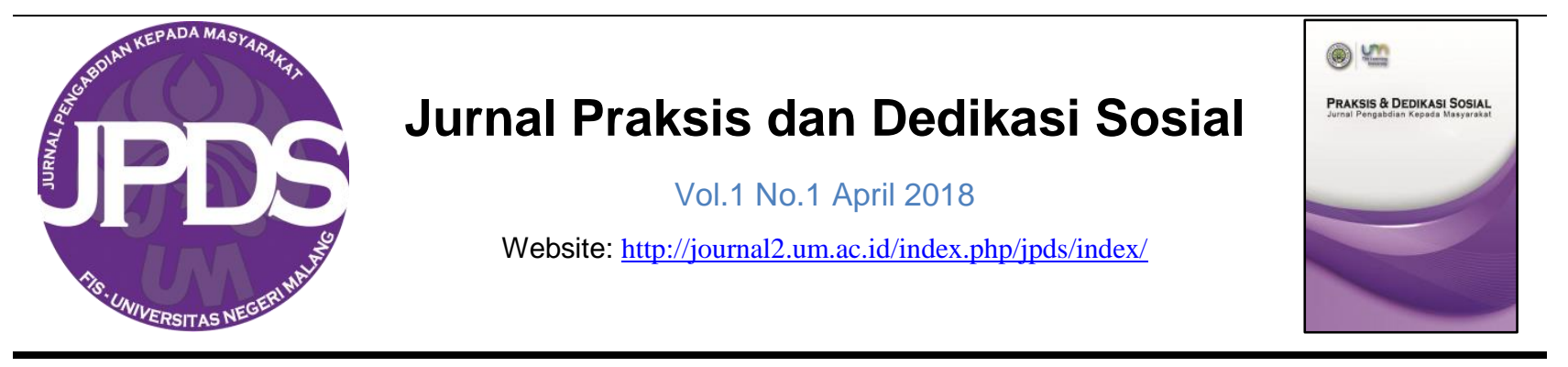

\title{
RELIEF CANDI KIDAL SEBAGAI INSPIRASI PENGEMBANGAN MOTIF BATIK KHAS DESA KIDAL UNTUK PEMBERDAYAAN MASYARAKAT
}

\author{
Indah Wahyu Puji Utami ${ }^{1}$, Slamet Sujud Purnawan Jati ${ }^{2}$, Ari Sapto ${ }^{3}$ \\ 1,2,3 Jurusan Sejarah, Fakultas IImu Sosial, Universitas Negeri Malang. \\ Diterima 28 Maret 2018, dipublikasikan 30 April 2018.
}

\begin{abstract}
Abstrak
Tujuan kegiatan pengabdian kepada masyarakat ini adalah untuk mengembangkan motif batik khas Desa Kidal untuk pemberdayaan masyarakat. Metode pengembangan yang dilakukan meliputi observasi, eksplorasi ide, perancangan dan perwujudan karya. Mitra yang terlibat dalam kegiatan ini adalah pemerintah Desa Kidal, PKK Desa Kidal, Karang Taruna Garudeya, dan Koperasi Wanita (Kopwan) Melati. Hasil dari kegiatan ini adalah adanya lima motif batik khas Desa Kidal yaitu Garudeya, ayam, pelipit kakaktua, tumpal, dan lidah api. Motif tersebut diaplikasikan dalam bentuk canting cap batik. Adanya motif dan canting cap batik memberdayakan 28 perempuan Desa Kidal yang merupakan bagian dari kelompok mitra sehingga mereka bisa mengembangkan produksi batik yang bernilai ekonomi.
\end{abstract}

\section{Kata Kunci}

Desain, Motif Batik, Relief Candi Kidal, Pemberdayaan Masyarakat.

\section{PENDAHULUAN}

Desa Kidal terletak di Kecamatan Tumpang, Kabupaten Malang, Jawa Timur. Desa Kidal memiliki iklim seperti desa-desa lain di Indonesia, yaitu kemarau dan penghujan. Kondisi ini memungkinkan mayoritas penduduk desa Kidal untuk memiliki mata pencaharian utama bertani dan berternak. Pertanian desa ini berupa sawah dan perkebunan. Peternakan desa ini antara lain ayam dan sapi.

Sebagian besar penduduk Desa Kidal adalah buruh tani dengan penghasilan yang kecil dan tidak menentu. Buruh tani tersebut sebagian besar adalah laki-laki karena pemilik tanah lebih memilih mempekerjakan buruh laki-laki yang dianggap lebih kuat daripada perempuan. Oleh karenanya, perempuan di desa ini banyak yang tidak bekerja dan hanya mengurus rumah tangga. Mereka tidak banyak berkontribusi pada perekonomian keluarga.

Ada pula perempuan-perempuan Desa Kidal yang bekerja di Hongkong dan Taiwan sebagai buruh migran di sektor domestik (pengasuh anak, perawat orang jompo, atau pembantu rumah tangga). Mereka melakukan itu untuk membantu

\footnotetext{
${ }^{1}$ Surel korespondensi: indahwahyu.p.u@um.ac.id
} 
Relief Candi Kidal Sebagai Inspirasi Pengembangan Motif Batik Khas Desa Kidal...

perekonomian keluarganya. Namun, kepergian kaum ibu bekerja di luar negeri menimbulkan masalah sosial, terutama pada kenakalan remaja. Oleh karenanya, diperlukan suatu upaya pemberdayaan perempuan Desa Kidal agar mereka bisa memiliki penghasilan dan berkontribusi pada pereknomian keluarga tanpa harus bekerja di luar negeri.

Salah satu upaya yang dapat dilakukan adalah dengan mengembangkan usaha kecil batik. Produksi batik merupakan usaha yang padat karya karena melibatkan banyak orang dalam pengerjaannya. Dengan demikian, akan ada banyak perempuan Desa Kidal yang bisa bekerja pada sektor ini.

Pengembangan usaha batik memang tidak mudah, terutama jika pengrajin tidak memiliki motif khas yang membedakannya dengan batik lain. Oleh karenanya perlu dikembangkan motif khas Desa Kidal yang unik. Motif ini dapat dikembangkan dari relief Candi Kidal yang merupakan potensi wisata sejarah di desa ini.

Desa Kidal memiliki peran penting dalam perjalanan sejarah Indonesia karena menyimpan peninggalan akeologis yang menarik minat wisatawan. Secara umum Candi Kidal terletak di lembah Gunung Bromo sebelah barat dengan ketinggian atas permukaan laut (Sedyawati, 2010). Candi Kidal pertama kali dilaporkan oleh B. de Haan dan J. F. G. Brumund pada tahun 1926. Sejak saat itu sampai sekarang, Candi Kidal masih menarik wisatawan untuk meneliti maupun berwisata.

Candi Kidal bersifat agama HinduSiwa karena di ruangan candi (garbhagrha) dahulunya terdapat arca Siwa Mahadewa yang sekarang disimpan di Royal Tropical Institute di Amsterdam (Sedyawati, 2014). Peninggalan Candi Kidal ini menunjukkan bahwa dulu masyarakat Malang, khususnya desa Kidal, menganut agama Hindu beraliran Siwa. Candi Kidal juga menjadi bukti bahwa desa Kidal pada masa kerajaan Singosari termasuk wilayah yang penting dan sakral. Candi Kidal masih digunakan untuk beribadah pada saat-saat tertentu tapi tidak seintensif dulu pada masa Kerajaan Singosari.

Sebagian besar relief Candi Kidal masih bisa dilihat dengan jelas. Pada kaki candi, tiga sisinya (utara, timur, dan selatan) terdapat relief timbul motif garuda yang merupakan fragmen dari cerita Garudeya. Apabila kita berjalan mengelilingi candi mengikuti arah jarum jam (pradaksina), berturut-turut terlihat fragmen cerita garuda menggendong ibunya Sang Winata (utara), garuda membawa guci air amrta (timur), dan garuda dengan ular naga (selatan) 
(Sedyawati, 2010). Relief-relief ini memiliki filosofi yang mendalam.

Relief-relief ini cocok untuk dijadikan ide untuk membuat dan mengembangkan batik khas Candi Kidal. Pengembangan motif batik khas Desa Kidal yang berasal dari relief Candi Kidal diharapkan dapat menggugah masyarakat, terutama kaum perempuan, untuk belajar dan mengembangkan usaha batik. Dengan demikian pengembangan motif ini akan memberdayakan masyarakat sekitar lokasi Candi Kidal.

\section{METODE}

Metode yang digunakan yaitu observasi, eksplorasi, perancangan dan perwujudan karya. (a) Observasi lapangan dilakukan untuk mengamati secara langsung berbagai relief yang ada di Candi Kidal. (b) Eksplorasi ide yang berupa penjelajahan pikiran dalam menggali sumber ide. Focus Group Discussion (FGD) yang melibatkan perangkat desa, akademisi, pemangku budaya, dan kelompok mitra juga dilakukan dalam tahap ini. (c) Perancangan yang terdiri dari kegiatan menuangkan ide hasil eksplorasi ke dalam wujud desain motif. (d) Perwujudan karya, merupakan proses pembuatan kain batik dengan menerapkan desain motif dari hasil perancangan.

Berikut merupakan prosedur kerja yang digunakan dalam pelaksanaan program pengabdian kepada masyarakat kali ini:

\section{Observasi}

Observasi dilakukan untuk mengumpulkan data melalui pengamatan secara langsung relief-relief yang ada di Candi Kidal. Di Candi ini terdapat relief cerita Garudeya yang merupakan relief utama. Selain itu juga terdapat berbagai relief ornamentasi berupa medallion, tumpal, flora dan fauna.

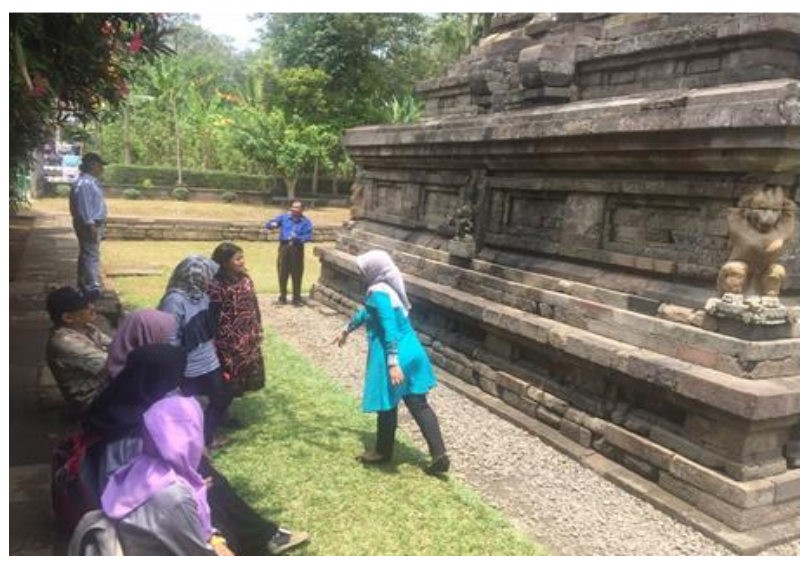

Gambar 1. Observasi ke Candi Kidal

(Sumber: Dokumentasi Bina Desa Kidal, 2017)

\section{Eksplorasi Ide}

Eksplorasi ide dilakukan dengan mengembangkan ide atau gagasan berdasarkan hasil observasi. Tim mendapati ada beberapa relief yang potensial untuk dikembangkan sebagai motif batik, baik yang berasal dari relief cerita maupun ornamentasi. Untuk memilih relief yang akan dikembangkan menjadi motif, maka dilakukan proses FGD yang melibatkan pihak kepala pemerintah Desa Kidal, akademisi dari Universitas Negeri Malang terutama ahli bidang sejarah kebudayaan Indonesia masa 

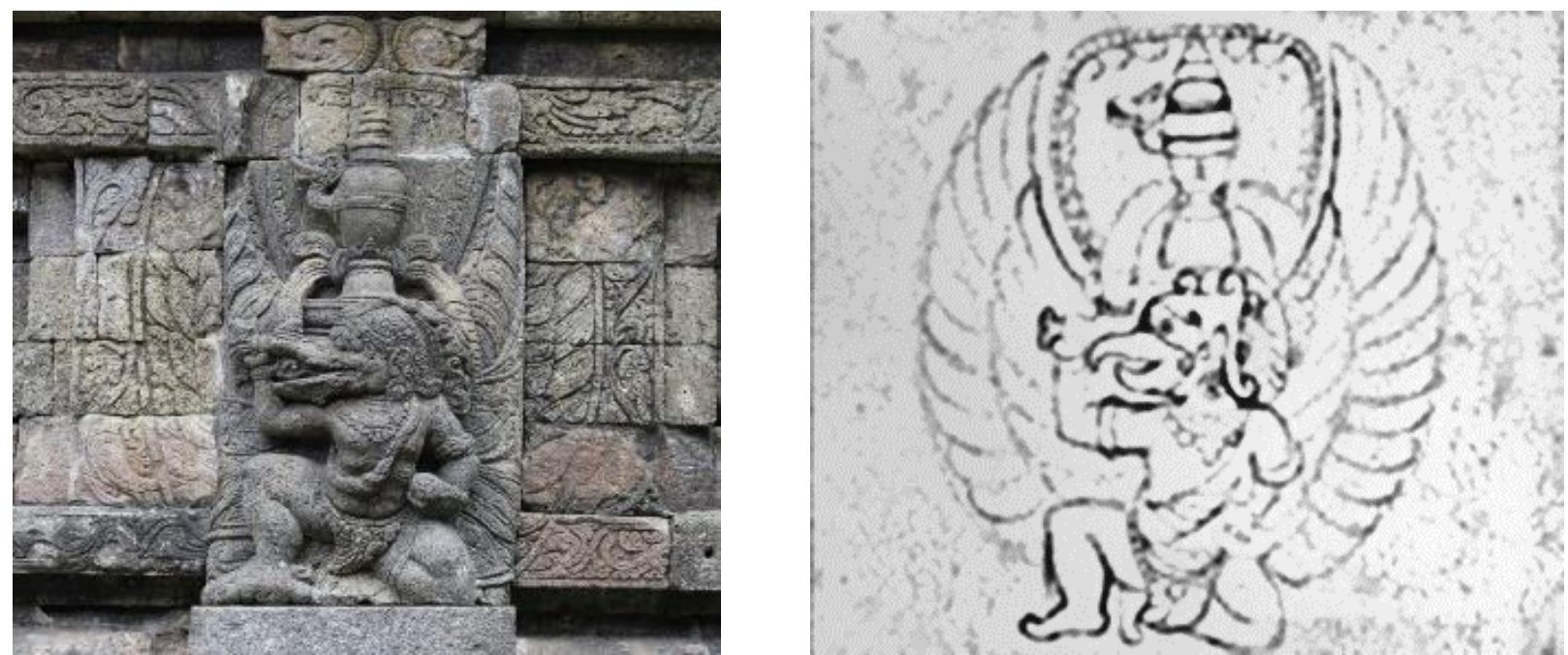

Gambar 2. Desain Motif dari Relief Cerita Garudeya pada Sisi Timur Candi, (Sumber: Dokumentasi Bina Desa Kidal, 2017).
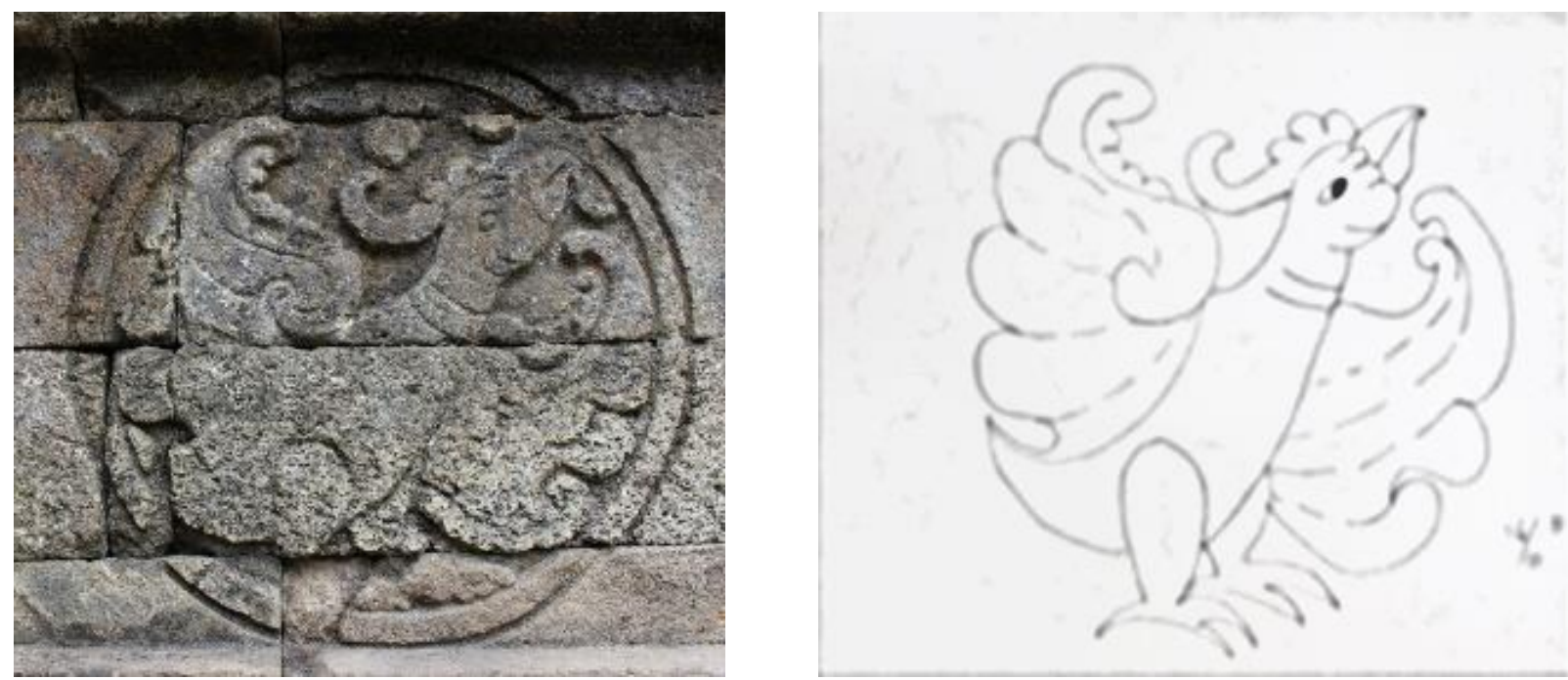

Gambar 3. Desain Motif Batik dari Relief Ornamentasi Medalion Ayam Jago, (Sumber: Dokumentasi Bina Desa Kidal, 2017).
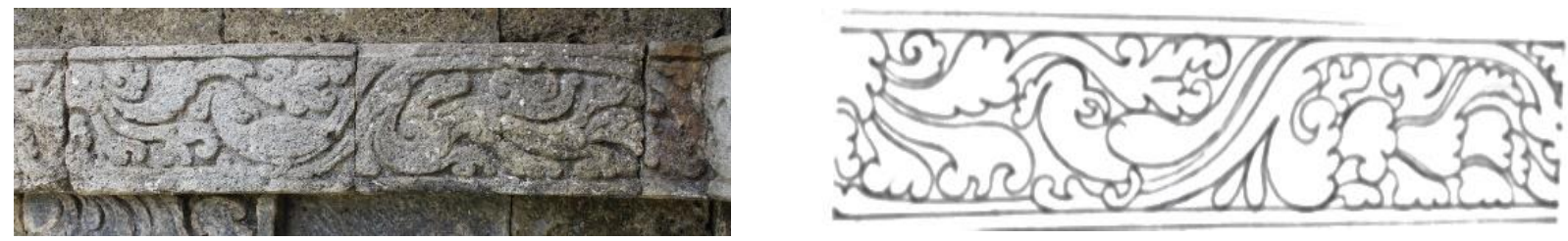

Gambar 4. Desain Motif Batik dari Relief Ornamentasi Pelipit Kakaktua, (Sumber: Dokumentasi Bina Desa Kidal, 2017).

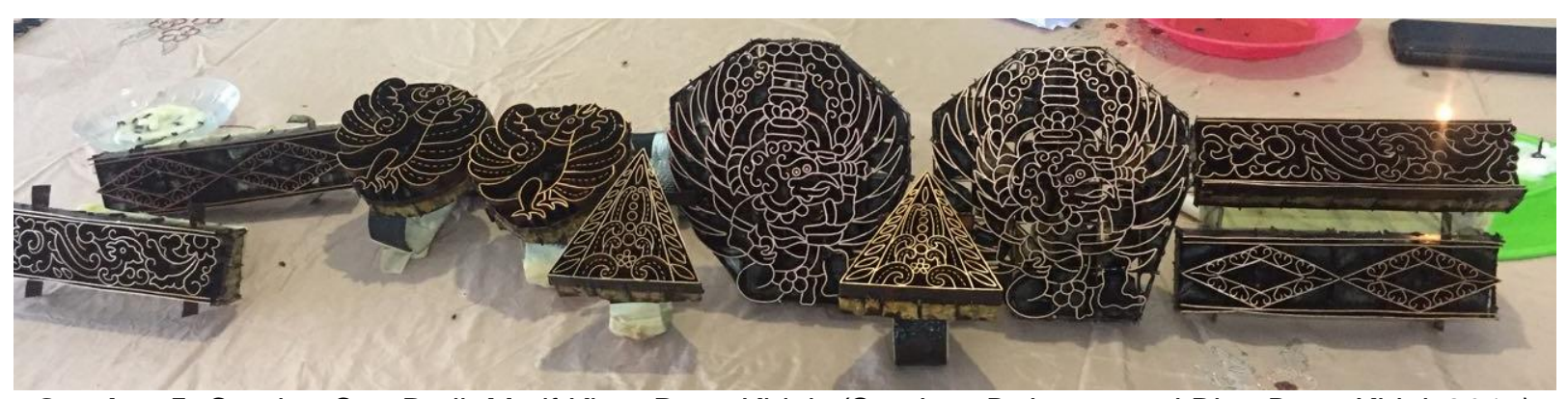

Gambar 5. Canting Cap Batik Motif Khas Desa Kidal, (Sumber: Dokumentasi Bina Desa Kidal, 2017). 
Hindu Budha, tokoh agama Hindu karena relief candi ini juga memuat unsur mitologis yang masih dipakai oleh umat Hindu hingga saat ini, juru pelihara Candi Kidal, pemangku budaya, tokoh masyarakat. FGD juga melibatkan kelompok mitra yang ada di Desa Kidal yaitu PKK Desa Kidal, Karang Taruna Garudeya, dan Koperasi Wanita (Kopwan) Melati. FGD menghasilkan keputusan yang merupakan 5 relief yang akan dikembangkan ke dalam wujud desain motif batik. Relief cerita Garudeya yang ada pada sisi timur candi dipilih sebagai motif utama. Sementara relief ornamentasi lainnya yang terdiri dari relief medalion ayam, relief pelipit kakaktua, relief tumpal dan relief lidah api dipilih sebagai motif tambahan.

\section{Perancangan}

Tahapan ini terdiri dari kegiatan menuangkan ide yang dihasilkan ke dalam bentuk sketsa motif. Ada beberapa sketsa motif yang dibuat dalam bentuk alternatif untuk dipilih yang terbaik. Sketsa motif kemudian disempurnakan menjadi desain motif yang kemudian dibuatkan canting cap batik dari tembaga. Beberapa contoh desain motif yang dikembangkan dapat dilihat pada gambar 2 sampai dengan 5 di atas.

\section{Perwujudan Karya}

Proses perwujudan karya diawali dengan penyediaan bahan dan alat yang kemudian dilanjutkan dengan proses pembuatan kain batik. Proses pengerjaannya dengan menggunakan teknik batik cap dan pewarnaan celup.

\section{Bahan dan Alat}

Bahan dan alat yang digunakan terdiri dari bahan dan alat untuk membuat desain dan untuk membuat batik. Bahan dan alat yang digunakan untuk membuat desain adalah kamera, kertas gambar, pensil dan penghapus. Sementara itu bahan untuk membuat batik adalah kain primis, lilin batik, pewarna batik, air, dan waterglass. Alat yang digunakan untuk membatik adalah meja batik cap, canting cap, kompor gas, bak pewarna, kresek, bak pencucian, panci pelorodan, penjemuran teduh, dan setrika.

\section{Proses Pembuatan Kain Batik}

Proses pembuatan batik diikuti oleh 28 perempuan warga Desa Kidal yang merupakan anggota PKK, Karang Taruna Garudeya, dan Kopwan Melati. Kegiatan ini diawali dengan menempelkan lilin pada kain dengan menggunakan canting cap. Selanjutnya kain yang telah dicap, dicelup ke dalam pewarna dan waterglass. Kain kemudian dimasukkan ke dalam kresek dan didiamkan selama tiga jam. Setelah itu, kain dilorod, dicuci dan dijemur. Kain yang telah kering kemudian disetrika.

\section{HASIL DAN PEMBAHASAN}

Candi Kidal terletak di Desa Kidal, Kabupaten Malang. Candi ini merupakan tempat pendharmaan raja Anusapati yang diduga selesai dibangun tahun 1260 (Turaeni, 2015). Bangunan candi terbuat dari batu andesit dan memiliki karakteristik khas candi masa Singhasari. Struktur bangunannya terdiri dari bagian kaki, tubuh, dana tap candi. Struktur ini mengacu pada penggambaran tentang meru yang diyakini sebagai gunung suci dalam mitologi Hindu. Dalam mitologi ini, meru diyakini sebagai tempat tinggal para dewa. Konsep gunung mengandung unsur 
Relief Candi Kidal Sebagai Inspirasi Pengembangan Motif Batik Khas Desa Kidal...

flora dan fauna sehingga di Candi ini terdapat banyak relief yang menggambarkan berbagai hewan dan tanaman. Selain itu juga ada relief tentang makhluk-makhluk mitologis misalnya Garudeya. Berbagai relief yang ada di candi ini memiliki bentuk yang indah dan masih bisa dilihat hingga saat ini. Relief-relief itulah yang dikembangkan sebagai motif batik khas Desa Kidal.

\section{Motif Batik Garudeya}

Relief Garudeya merupakan relief cerita pada Candi Kidal. Cerita Garudeya merupakan salah satu kisah dalam mitologi Hindu. Dalam kisah ini, Garudeya berusaha membebaskan ibunya yang bernama Winata dari perbudakan Kadru. Relief Garudeya dipahatkan mulai dari sisi tangga sebelah utara searah jarum jam hingga sisi tangga sebelah selatan candi.

Ada tiga panil cerita Garudeya yang dipahatkan pada Candi Kidal. Relief pertama yang berada di sebelah utara candi menggambarkan Garudeya sedang menopang ekor naga yang ada di kepalanya. Panil ini menceritakan tentang Garudeya membantu ibunya yang diperbudak Winata mengasuh para ular. Para ular ini adalah anak Winata. Garudeya berusaha mencari tirta amerta untuk membebaskan ibunya dari perbudakan yang dilakukan oleh Kadru. Dalam perjalanan ini, ia harus menghadapi berbagai rintangan untuk mendapatkan tirta amerta yang dijaga oleh para dewa (Turaeni, 2015). Meskipun memiliki makna yang baik, namun panil relief ini tidak sempurna. Bagian atas relief ini sudah rusak sehingga sulit untuk direkonstruksi dan dibuat gambar motif batik.
Panil relief sebelah selatan menggambarkan Garudeya menopang seorang perempuan. Relief ini menceritakan keberhasilan Garudeya membebaskan ibunya dari perbudakan Kadru. Relief ini menggambarkan nilai pengabdian anak terhadap ibunya. Namun, kondisi relief ini sudah tidak utuh. Fragmen kepala sosok perempuan dalam relief ini sudah tidak ada. Oleh karena itu, relief ini tidak dipilih untuk dikembangkan sebagai motif batik karena akan menyulitkan proses desain.

Panil relief Garudeya yang dipilih untuk dikembangkan adalah relief yang berada di sebelah timur. Panil ini menggambarkan Garudeya membawa kendi yang berisi tirta amerta. Hal ini bermakna bahwa Garudeya berhasil mengatasi berbagai rintangan dan mendapatkan air amerta yang ia cari untuk menebus ibunya dari perbudakan. Dibandingkan dengan panil relief cerita Garudeya lainnya yang ada di bangunan Candi Kidal, panil ini merupakan yang relatif masih utuh. Oleh karenanya, relief ini dipilih untuk dikembangkan sebagai salah satu motif khas Desa Kidal.

Garudeya merupakan makhluk mitologis dalam agama Hindu. la merupakan wahana atau kendaraan Dewa Wisnu. Oleh karenanya, ia termasuk makhluk yang dianggap suci. Pemuka agama Hindu yang terlibat dalam kegiatan FGD memperbolehkan relief ini dikembangkan sebagai motif batik asalkan distilir, artinya tidak digambarkan sama persis dengan yang di relief. Selain itu, ia juga mengharapkan agar batik dengan motif Garudeya tidak dipakai sebagai sarung, 
celana, atau rok karena dikhawatirkan akan menyinggung umat Hindu.

Berdasarkan pertimbangan tersebut, maka dibuatlah desain motif Garudeya sebanyak dua buah. Desain motif pertama menstlisir relief Garudeya hingga menyerupai penggambaran pada wayang. Namun desain ini kurang disukai oleh kelompok mitra karena penggambaran Garudeya pada desain tersebut terkesan kurang gagah, sehingga mereka memilih desain motif kedua. Motif ini berukuran diameter $20 \mathrm{~cm}$. Desain motif ini bisa dilihat pada gambar 2. Berikut adalah gambaran dari motif batik Garudeya yang diaplikasikan pada kain primis.

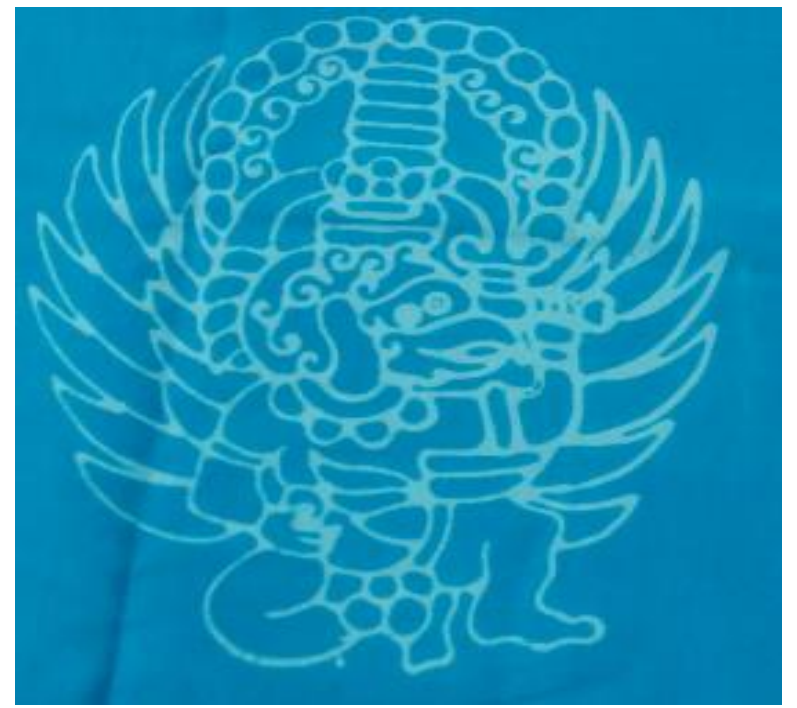

Gambar 6. Motif Batik Garudeya, (Sumber dokumentasi pribadi).

\section{Motif Batik Ayam}

Pengembangan desain motif batik khas memang sering kali bersumber dari potensi ekonomi suatu wilayah. Sebagai contoh, batik Kediri memiliki motif manga podang yang merupakan hasil alam yang khas dan terkenal di wilayah ini (Prahastuningtyas \& Rizkiantono, 2016). Daerah Prigen juga memiliki motif batik matoa yang merupakan potensi tanaman buah yang bernilai ekonomi di sini (Widodo \& Ponimin 2017). Oleh karenanya motif kedua yang dikembangkan terkait dengan potensi eknomi Desa Kidal yaitu peternakan ayam. Sekitar 30\% penduduk Desa Kidal adalah peternak ayam, baik ayam petelur maupun bukan ras.

Motif ayam yang dikembangkan diambil dari penggambaran ayam pada relief medalion yang berisi gambar fauna. Relief ayam yang dikembangkan adalah relief ayam jago yang sedang mengepakkan sayapnya. Relief ini dibingkai oleh medalion. Masyarakat menganggap relief ini merepresentasikan salah satu sumber perekonomian mereka.

Motif ayam tidak dijadikan motif utama, melainkan sebagai motif isen. Hal ini karena masyarakat menginingkan agar motif Garudeya yang menjadi motif utama. Oleh karenanya ukuran motif ini lebih kecil dari motif garudeya, yaitu berdiameter $10 \mathrm{~cm}$.

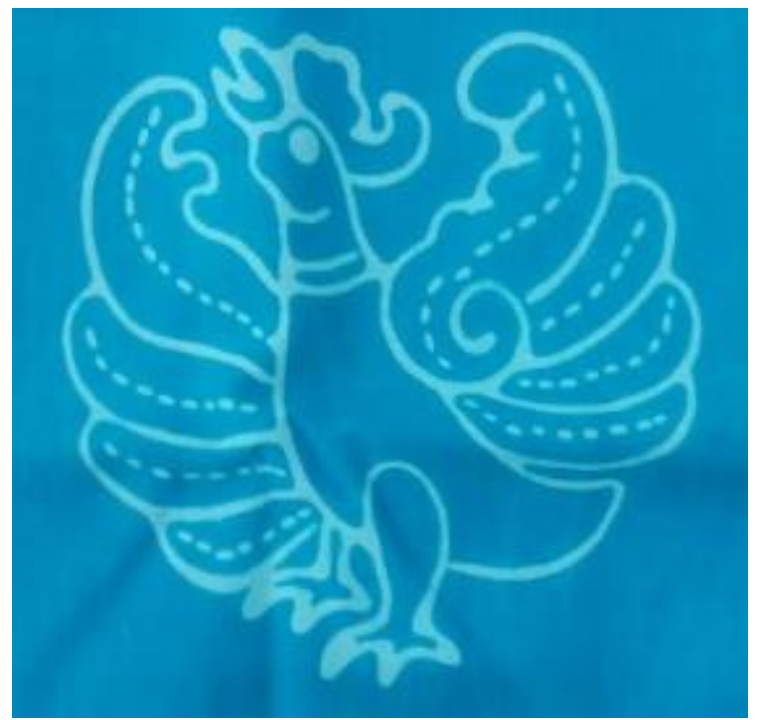

Gambar 7. Motif Batik Ayam, (Sumber dokumentasi pribadi).

gambar 7 diatas adalah contoh dari motif batik ayam yang diaplikasikan pada kain primis. 
Relief Candi Kidal Sebagai Inspirasi Pengembangan Motif Batik Khas Desa Kidal...

\section{Motif Batik Pelipit Kakaktua}

Candi Kidal memiliki banyak relief ornamentasi. Salah satunya adalah relief pelipit fauna berupa burung kakaktua. Ada beberapa relief pelipit burung kakaktua di Candi Kidal, namun peserta FGD memilih relief pelipit kakaktua yang menoleh ke belakang. Pemilihan relief ini karena penggambarannya jelas dan indah sehingga akan mudah untuk dituangkan dalam bentuk desain motif batik.

Motif ini berupa pelipit sehingga cocok dikembangkan sebagai motif pinggiran batik. Motif pinggiran merupakan motif yang khusus dipakai hiasan pinggir kain atau untuk batas antara bidang yang berpola dengan bidang yang kosong tidak berpola (Azizah, 2015). Berikut adalah aplikasi relief motif pinggiran/pelipit kakaktua yang menoleh ke belakang.

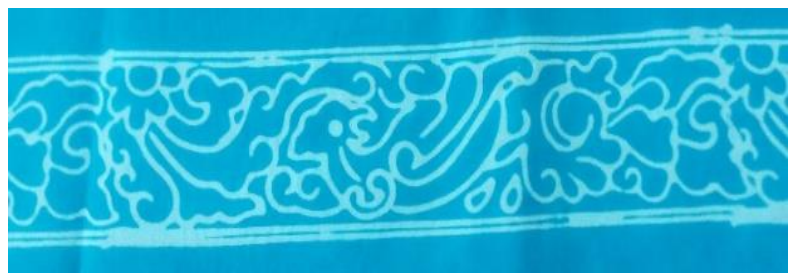

Gambar 8. Motif Batik Pelipit Kakaktua, (Sumber dokumentasi pribadi).

\section{Motif Batik Tumpal}

Motif pinggiran lain yang dikembangkan adalah motif tumpal yang berasal dari relief ornamentasi pada candi Kidal. Relief tumpal yang dikembangkan berasal dari bagian pelipit atap candi. Motif ini hanyalah motif dekoratif untuk memperkaya khazanah motif batik khas Desa Kidal. Motif ini merupakan motif yang paling sederhana dari motif-motif yang dikembangkan. Hal ini dilakukan untuk memenuhi usulan kelompok mitra yang menginkan motif yang tidak terlalu rumit. Berikut adalah aplikasi motif batik tumpalkhas Desa Kidal pada kain primis.

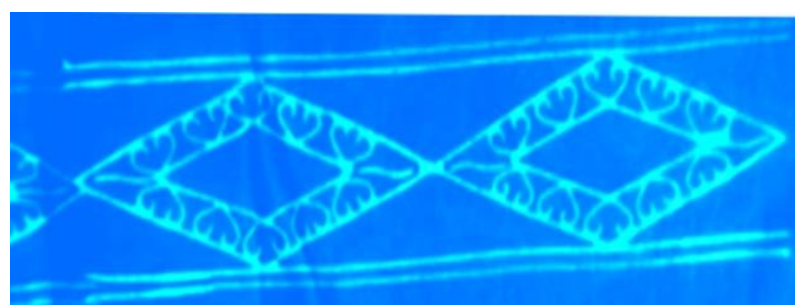

Gambar 9. Motif Batik Tumpal, (Sumber dokumentasi pribadi).

\section{Motif Batik Lidah Api}

Motif lain yang dikembangkan sebagai motif batik khas Desa Kidal adalah motif batik lidah api. Motif ini dikembangkan dari relief yang terdapat pada bagian atap Candi Kidal. Motif ini merepresentasikan lidah api matahari yang ada di langit.

Motif lidah api di sini berfungsi sebagai motif pengisi. Motif pengisi ialah motif-motif yang berfungsi sebagai pengisi bidang untuk

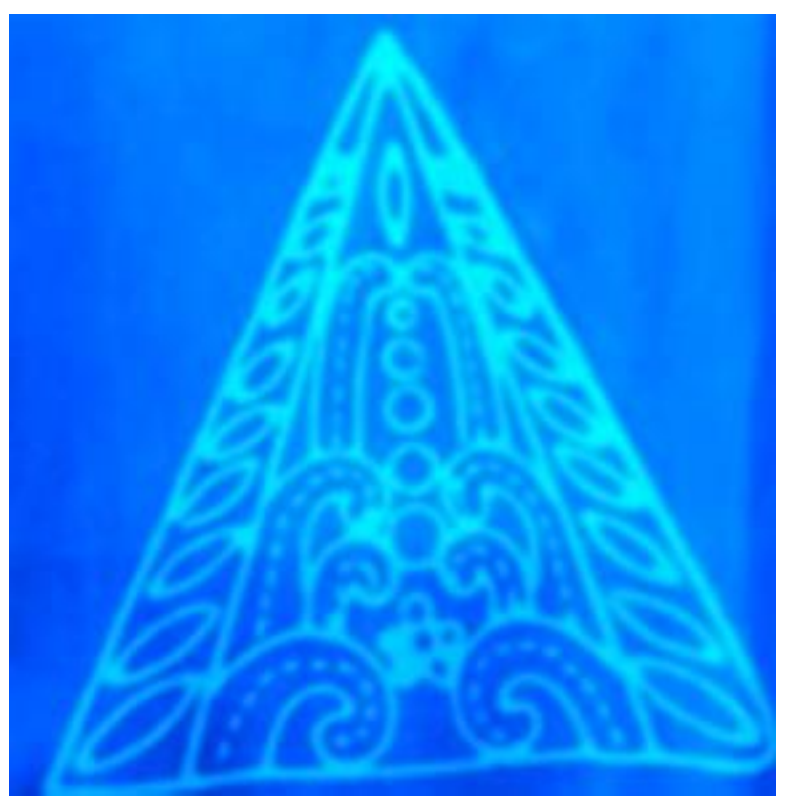

Gambar 10. Motif Batik Lidah Api, (Sumber dokumentasi pribadi).

memperindah batik secara keseluruhan (Azizah 2015). Motif ini berukuran lebih kecil dari motif utama. Motif lidah api khas Desa Kidal berukuran tinggi $10 \mathrm{~cm}$ dan lebar $10 \mathrm{~cm}$. 
Berikut adalah aplikasi motif batik lidah api pada kain primis.

\section{Kendala yang Dihadapi dan Upaya Mengatasinya}

Candi Kidal memang memiliki berbagai motif yang menarik untuk dikembangkan sebagai motif batik. Mekipun demikian, ada beberapa kendala yang dihadapi dalam pengembangan desain notif batik khas Desa Kidal ini, yaitu kendala pemilihan motif, kendala desain motif, dan kendala aplikasi motif dalam bentuk canting cap.

Kendala pemilihan motif terutama terjadi karena banyaknya motif yang indah pada relief di Candi Kidal. Banyaknya relief ini justru menimbulkan kesulitan karena kelompok mitra dan pelaksana kegiatan harus menentukan prioritas motif mana yang akan dikembangkan. Guna mengatasi masalah ini, maka dilakukan FGD. Namun, pada saat FGD masik terdapat kendala yaitu terlalu banyak masukan dari pihak mitra sehingga tidak mungkin semuanya bisa diakomodir untuk dibuat desain batiknya. Namun, kepala desa pada akhirnya bisa menyelesaikan masalah tersebut dengan memediasi peserta FGD untuk memilih lima motif saja.

Kendala berikutnya terkait dengan desain motif. Relief yang dipilih merupakan relief yang berasal dari abad XIII sehingga beberapa relief sudah agak aus. Hal ini tentu saja menjadi tantangan tersendiri bagi desainer untuk mengembangkan relief menjadi motif batik. Selain itu ada pula relief yang dianggap suci sehingga penggambarannya tidak boleh sama persis dengan relief. Namun, berbagai kendala tersebut akhirnya data diatasi.
Kendala terakhir terkait dengan aplikasi desai motif ke dalam canting cap. Desain motif yang terlalu rapat dan rumit ternyata menyulitkan proses pembuatan canting cap. Selain itu, ada kekhawatiran dari pembuat cap jika dibuat terlalu detail dan rumit malah akan menyulitkan proses pewarnaan. Oleh karenanya, desain yang telah dibuat kemudian disederhanakan lagi.

\section{Dampak Pengembangan Motif Batik Berdasarkan Relief Candi Kidal untuk Pemberdayaan Masyarakat}

Canting cap yang dikembangkan berjumlah sepuluh buah dengan rincian masing-masing motif sebanyak dua cap. Hal ini dilakukan agar kegiatan produksi batik cap bisa berjalan dengan cepat. Masyarakat dan kelompok mitra yang terlibat merasa senang dengan pembuatan canting cap dengan motif khas Desa Kidal.

Kelompok mitra sebelumnya sudah pernah mengikuti pelatihan batik yang dilakukan oleh Dinas Perindustrian dan Perdagangan (Disperindag) Kabupaten Malang. Namun, pelatihan tersebut adalah untuk batik tulis. Mereka mengeluhkan proses pembuatan batik tulis yang lama. Hal ini berbeda dengan batik dengan teknik cap. Mereka merasa senang karena proses pelekatan malam pada kain bisa dilakukan sangat cepat, hanya sekitar 5-10 menit untuk kain berukuran 2 meter. Selain itu, pada pelatihan sebelumnya mereka belum memiliki motif khas daerahnya. Mereka memang diminta Disperindag Kabupaten Malang untuk mengembangkan motif khas tapi mengalami kesulitan. Adanya pengembangan motif khas 
Desa Kidal yang berasal dari relief Candi Kidal membuat kelompok mitra merasa sangat senang. Mereka juga bangga bisa memiliki motif khas sendiri.

Kelompok mitra kemudian memproduksi secara mandiri kain batik yang mengkombinasikan dua atau lebih motif dari motif yang telah dikembangkan. Para perempuan yang sebelumnya tidak memiliki penghasilan sendiri kemudian memiliki keinginan untuk belajar memproduksi batik yang bernilai ekonomi. Hasil produksi tersebut mereka gunakan sendiri dan ada pula yang dipasarkan melalui pameran-pameran. Dengan demikian kegiatan pengembangan motif batik dari relief Candi Kidal dapat memberdayakan masyarakat, terutama kaum perempuan yang ada di Desa Kidal.

\section{KESIMPULAN}

Kekayaan relief Candi Kidal yang sangat indah dapat menjadi sumber inspirasi untuk mengembangkan motif batik khas Desa Kidal. Ada lima motif batik khas Desa Kidal yang dihasilkan dari relief tersebut, yaitu motif Garudeya, ayam, pelipit kakatua, tumpal, dan lidah api. Motif-motif tersebut dibuat canting cap sehingga memudahkan proses pembuatan batik khas Desa Kidal. Pembuatan motif khas Desa Kidal yang bersumber dari relief Candi Kidal. Motif tersebut kemudian dimanfaatkan oleh masyarakat, terutama kaum perempuan yang tidak bekerja, untuk memproduksi batik. Hal ini merupakan salah satu bentuk pemberdayaan masyarakat.

\section{UCAPAN TERIMA KASIH}

Penulis menyampaikan terima kasih kepada Fakultas IImu Sosial (FIS) Universitas Negeri Malang (UM) yang mendanai kegiatan Bina Desa 2017 di Desa Kidal, Kabupaten Malang. Penulis juga menyampaikan terima kasih kepada pihak-pihak yang mendukung kegiatan Bina Desa 2017 yaitu Jurusan Sejarah FIS UM, Desa Kidal, PKK Desa Kidal, Karang Taruna Garudeya, Koperasi Wanita Melati, Batik Tulis Claket, M. Azizil dan tim editor dari Jurnal Praksis dan Dedikasi Sosial (JPDS), Fakultas IImu Sosial-Universitas Negeri Malang.

\section{DAFTAR RUJUKAN}

Azizah, Z. D. 2015. Deformasi Flora dan fauna dalam Motif Batik pada Pembelajaran Seni Budaya Kelas VIIIC SMPN 1 Turi. Skripsi, Yogyakarta: Universitas Negeri Yogyakarta.

Prahastuningtyas, Y. dan R. Eka Rizkiantono. 2016. "Perancangan Motif Batik Berkarakter Kediri." Jurnal Sains dan Seni ITS 5 (2): 237-242.

Sedyawati, Edi. 2010. Budaya Indonesia: Kajian Arkeologi, Seni, dan Sejarah. Jakarta: Rajawali Pers.

Sedyawati, Edi. 2014. Kebudayaan di Nusantara: dari keris, tor-tor, sampai industri budaya. Depok: Komunitas Bambu.

Turaeni, N. N. T. 2015. "Aplikasi Adi Parwa dalam Relief Situs Candi Kidal." Forum Arkeologi 28 (2): 131-144.

Widodo, T. dan Ponimin. 2017. "Desain Produk Batik Sentra Prigen Lereng Gunung Welirang Artistik dan Berkarakter." Journal of Art, Design, Art Education and Culture Studies 2 (2): 6373. 